\title{
On the Translation of Voices, ACCEnts, TONGUes: SCOTTISH POETS COMMEMORATING ROBERT BURNS TODAY
}

\section{ANIELA KORZENIOWSKA}

In 2009, Scotland was celebrating the two hundred and fiftieth anniversary of the birth of Robert Burns, the country's world-famous and greatest national bard. Although he showed a natural talent for rhyming and writing poetry from an early age, it was mainly thanks to his chosen linguistic medium that he became such a favourite - despite politically motivated fluctuating fame throughout the centuries - among both the young and the old, all classes of society and every walk of life. Choosing to write primarily in Scots when emphasis throughout the country after the Union of Parliaments in 1707 was to adopt Metropolitan English as a literary medium, Burns was quite deliberately going against the tide and the general trend of his times. Some of his best and most famous poems were written in 1784-1786, in which, among others, we can learn about his views on religious hypocrisy and social injustice. It was a time when throughout Britain social and political unrest was rife and Burns was not one to keep his feelings and politics to himself. Throughout his short literary life his poetry would quite forcefully - also often with great irony and subtle humour - reveal his political views, his growing radicalism and nationalist feelings. This, however, was often done anonymously or under various pseudonyms.

Burns's first collection of verse appeared in 1786 under the title Poems. Chiefly in the Scottish Dialect and was known as the 'Kilmarnock Edition'. It was followed by a revised 'Edinburgh Edition' in 1787 and an American publication the year after. It is the title of this first collection that has been borrowed for a recent anthology of poems New Poems. Chiefly in the Scottish Dialect, prepared and published in the 2009 anniversary year as a tribute to the bard.

It was one of Scotland's most significant contemporary poets and scholars, Robert Crawford - also Professor of Modern Scottish Literature at the University of St. Andrews - who approached some of the leading and most highly appreciated Scottish poets of today to supply a selection of new work for the above volume. The amazing response and quite striking poetic outcome has resulted in an anthology that reveals an astonishing range of possibilities of the Scottish and English tongues. It is also an interesting reflection of Scottish 
humour, linguistic insight, literary awareness - both national and international and last but not least, translation.

In reference to the title, the 'new poems' are indeed chiefly in the Scottish tongue although presenting various forms of spelling and phonetic transcription, reflecting the different voices and accents of the poets themselves. There is the tribute they wish to pay their famous predecessor, as clearly reflected in 'To a Mavis' by Kathleen Jamie, or more directly to their 'Mither Tongue' by John Burnside as well as in memory of 'An Ayrshire Mother', in which Tom Leonard refers to his own mother whose birthplace was the same as Burns's. The accent and language of Douglas Dunn, however, is presented through his 'English. A Scottish Essay', a poem written in English but showing the full linguistic, phonetic and political complexity of his native land.

Just to dwell for a moment on the first three above-mentioned contributions, 'To a Mavis' is a reference to Burns's famous poem 'To a Mouse', but all the former consists of is the following: 'On Discovering Two, Dead, in the Garden of Burns's Cottage, Alloway' (original italics). Just this and not a word more. The poem 'To a Mouse', on the other hand, is immediately followed by 'on turning her up in her nest with the plough, November, 1785'. We are confronted here with a reverse situation. The mouse will survive although its home has been thoughtlessly destroyed, while the mavis (singing thrush) is dead. Not just one bird, but two, while Burns's cottage has been preserved for posterity and his poems and songs are still with us today.

John Burnside's contribution consists of a poetic work divided into five sections. The last one, entitled Abroad (original italics), is not only written in his phonetically transcribed version of Scots, but also lays special emphasis on the significance of 'the mither tongue' and the feeling that the narrator has finally returned home:

Got here the nicht, efter years o wanderin, comin in oot the rain ...

but aw that really matters here is wakin, the body returned to the world like a map, or a windfa, the pit o the throat rehearsed in the mither tongue. 
It is the correspondence between one's own language and the feeling of belonging, issues so apparent in much of Robert Burns's own work, that is brought to the foreground here. This is what matters.

Tom Leonard, the third above-mentioned poet and a Glaswegian, wellknown for promoting in both his prose and poetry a phonetically transcribed version of his native city's speech forms, always and unchangeably emphasises the importance of one's own native/regional/local language, stressing that 'all livin language is [simply] sacred' (Leonard 1995: 120). In 'An Ayrshire Mother', apart from paying tribute to his own mother as well as to Burns, Leonard is also giving us a political and poetic image of his family, within which there too was controversy over the issue of allegiance and speech:
lik the folk acroass the road
$\mathrm{n}$ the kellys next door
ah pit oot a coronation flag
an tommy no pleased
coorss tommy's frae dublin
bit ahm scottish no irish
we're maybe a catholic faimily
bit she's oor queen inaw

Although Burns himself had nothing against Scotland being part of a greater Britain, much of his poetry expresses support for the Jacobite Cause of the past, portraying his stance against the Pitt government of his times and his antiHanoverianism generally. This issue of allegiance, whether it concerns the government and monarchy in London or the people of Scotland as such, with their need for political and social change, is also what has been taken up by Tom Leonard in the above quoted poem. When she puts out the flag - it would be the Union Jack - to celebrate Queen Elizabeth II's coronation in June 1953, her 'husband tommy' was 'no pleased'. She, however, is ready to celebrate the occasion because 'she's oor queen inaw'. We are faced with clearly defined political differences within one family, between the parents as well as between the mother and her son Tom. The poem characteristically ends with the line: 'tom speak proper', which rings a very familiar bell. In one of Leonard's most frequently quoted poems 'right inuff', his 'maw [also] tellt' him his 'language [was] disgraceful' (Leonard 1995: 120). The language he is supposed to be speaking is at least Standard Scottish English if not Metropolitan English. It is definitely not Glaswegian. At the same time, his mother herself speaks dialectal Scots.

Leonard, however, continues to be true to himself as well as to Burns, who wrote and promoted the speech of his people. It was the speech of the Scottish Lowlands that in the eighteenth century was fast disintegrating into many 
different dialectal forms, mainly because it was no longer encouraged in school education and was also gradually disappearing as a literary language. As far as Leonard today is concerned, 'his language' is Glaswegian, a form of speech that even Scottish linguists do not always wish to acknowledge as a variety of Scots, choosing rather to treat it as a bastardised form of English. Whatever the attitude and approach, though, it is one of many varieties spoken in Scotland and as such we can claim, following Leonard, that it is indeed sacred.

Douglas Dunn's tribute to Burns is the longest poem in the anthology and which, with the word 'essay' in its title, is a strong reminder of the seventeenthcentury 'Essay on Translated Verse' by Dillon Wentworth, Earl of Roscommon. Just as Dillon Wentworth discusses the issue of translated verse as he perceived it at the time of writing, Dunn presents his views on Scotland's complex linguistic situation against the country's historical background since 1707. Written in English because that happens to be the language he speaks and one of the three languages of Scotland, he says in his first two lines: 'I didn't choose you, nor did you choose me. / I was born into a version called Accent.'

We do not choose the language we are born into. Burns was born into Lallans (Lowland Scots), Leonard into Glaswegian, Douglas Dunn was born into what is called Standard Scottish English, a linguistic variety that follows all the grammatical and syntactic norms of English but is occasionally interspersed with what in Translation Studies are called cultural specific items: words, phrases, whole expressions that have their origins in Lowland Scots. And, of course, the Accent/Accents that are characteristic of the land north of the River Tweed.

In his 'Scottish Essay', Dunn refers to what he calls:

... the Robert Burns

Syndrome. - 'Just write like him, and you'll be true

To Scotland when its good old self returns.

Then you'll be true to us, and true to you.'

Dunn's disbelief of such notions is clear, being, according to him, harmful both to the poet/author and to Burns himself. He goes on to say pointedly 'English I'm not. As language, though, you're mine', highlighting the fact that there actually can be a difference between nationality and language. The two do not have to correspond, as affinity to a nation and a country do not have to go hand-in-hand with the language one is primarily aligned to. He goes on to place his emphasis on Scotland's unique linguistic richness:

... we've got three sound tongues

In which to utter poetry, and three

Good reasons, therefore, for our native songs

To triplicate our nationality. 
What brought about this phenomenon in the course of history can neither be reversed, nor does it need to be today. There is also no sense in blaming the past as:

Lives by its own slowly unfolding rules

.... Language

And chance morphologies, its shapes, and age,

Its histories the same as the people's.

...

Live and let live. Promote the various.

It can be said that it is indeed this 'various' that the contributors of the above mentioned anthology present as their tribute to Burns and to Scottish culture. Apart from the works that are wholly authentic and original - if we can negate the rather unquestionable statement promoted by Octavio Paz in his important text originally from 1971, “Translation: Literature and Letters”, that:

[o]n the one hand, the world is presented to us as a collection of similarities; on the other, as a growing heap of texts, each slightly different from the one that came before it: translations of translations of translations. Each text is unique, yet at the same time it is the translation of another text (Paz 1992: 154).

- the abundance of translations/borrowings/rewritings in Scots of works that first appeared far away from home is quite amazing, especially if we take into consideration the fact that the anthology consists of only 128 pages. There is, for example, Don Paterson’s 'The Poetry’ after Li Po, Jackie Kay’s rewriting of Hugh MacDiarmid's famous 'A Drunk Man Looks at the Thistle' which appears here as 'from A Drunk Woman Looks At Her Nipple'. We also have works 'eftir'/'efter' Cavafy, Hölderlin, Desnos, Montale and Pasolini, with interesting direct references to both Burns and Blake, as in W. N. Herbert's 'Rabbie, Rabbie, Burning Bright', for example. The range of poetic and linguistic possibilities also points to Scotland's penchant for diversity.

It also highlights a phenomenon that for centuries has been part of Scottish literature - translation. Awareness, interest and knowledge of foreign cultures were used to enhance and enrich native literature, and borrowing for the benefit of one's own writing was also part and parcel of the whole set-up. It is enough to recall the famous example of John Macpherson from the eighteenth century and his English-language Fragments of Ancient Poetry Collected in the Highlands of Scotland and Translated from the Gaelic or Erse Language (1760). The author of the introduction, Hugh Blair, at the time Professor of Rhetoric and Belles Lettres at Edinburgh University, speculated that parts of the great epic poetry of the thirdcentury hero Fingal, as related to his son Ossian, could still be heard in the Highlands of Scotland. Encouraged to do more research on the subject, the 
following year Macpherson duly brought out his Fingal: An Ancient Epic as told by the legendary bard Ossian. The work became a phenomenal success. As we know, the Poems of Ossian also enjoyed great popularity beyond the British Isles. The first Polish translation, for example, appeared during Macpherson's lifetime, in Warsaw in 1791. It was Osjana Kaledończyka trzy poematy by Konstanty Tyminiecki and was very soon followed by Ignacy Krasicki’s Pieśni Osjana (1792-93).

Although suspicion as to the authenticity of the 'translations' emerged relatively quickly, Macpherson never openly admitted to the forgery. The controversy over the issue was to last well into the twentieth century. What, however, is additionally interesting and is of relevance here is that it became a matter of Highland honour in particular, and Scottish honour generally, to defend Macpherson's works and their authenticity. This resulted in an anthology entitled Ancient Poems of Ossian, Orrann, Ullin, etc. (1787) including the Gaelic 'originals' of the 'translations'. In other words, what we could call 'back translations' of 'translations'. By appearing in different collections of ancient and modern Gaelic poems and songs, they "became part of Gaelic literature and literary tradition, despite the fact that their metre, language, and tone were outlandish from the Gaelic point of view" (Gillies 2000: 181).

The examples, however, of works included in the anthology discussed here which refer openly to being after Cavafy, Hölderlin, Li Po, Pasolini or Montale, to name just a few foreign influences, are of a somewhat different nature. Also each poet has obviously adopted a different strategy that would enhance the tribute they wished to make to Burns and his own literary output. Robert Crawford, for example, whose contribution, consisting of five poems and all presented as being 'eftir Cavafy', are in fact very Scottish and Burnsian in tone and reference, not to mention the linguistic medium (Scots) he uses. Of special note is the poem 'Kirk' which refers to love of the Scottish Kirk and the fact that the narrator, in hearing the ministers' Doric - a north-western variety of Scots - wrestling in their prayers, always thinks of those Scots 'wha's like us' - to quote Burns - and the inheritable glory of John Knox.

Hölderlin's great lyrics have their echoes in Kathleen Jamie's poems 'Hauf o Life' or 'Tae the Fates', while, for his ' 4 Atmospheres o' Montale an' wan "postcript" ' David Kinloch referred to such works by Robert Burns as the above mentioned 'To a Mouse', for example, and poems by both Montale and Pasolini, especially taking into consideration the latter's use of Italy's Friulian dialect. We have a feeling of the strong presence of Hugh MacDiarmid and the link between his use and promotion of Scots - with the abundant help of Scottish dictionaries and the same being the case of Kinloch himself. We have the Scottish, but also the international, the foreign enhancing the native, and a great deal thanks to different forms of translation, which are indeed translations of translations of translations. 
If we were, however, to move one step further and translate these 'translations of translations of translations' into yet one more language and culture, such as Polish for example, and bring the rich variety of Scottish literature closer to the contemporary Polish reader, what would our decisions be, what would we aim towards? How much of the associations, allusions to Burns and Scotland's multi-faceted past - linguistic, literary, historical, cultural in the full sense of the word - would we manage to preserve and make intelligible to our Polish target readers?

Burns, over a period of more than a hundred years - since 1872 - has been made known to quite a few generations of Polish readers, the best-known publication being $Z$ wierszy szkockich (1956), selected, introduced and edited by Stanisław Kryński. The collection of course was a translation of Burns's poems taken from Poems. Chiefly in the Scottish Dialect. In the introduction, Kryński clearly showed that the included works had been written in Scots, and it was from that language he, together with Zofia Kierszys and Ludmiła Marjańska, was translating from. His elucidating introduction helped to explain Scotland's complex historical background and the turbulent political events of Burns's lifetime.

It would obviously be difficult to expect the average Polish reader to fully understand and follow all the associations - both Scottish and foreign - made by the contributors of the 2009 publication New Poems. Chiefly in the Scottish Dialect, written as a celebratory tribute to Scotland's national bard, if the translator him/herself were not to become visible to the target reader. Just like Kryński in the past, we need to become a discernible participant of what Jerzy Jarniewicz calls "the polyvocal, dialogic character" of writing. He goes on to say that "[v]ersions, imitations, or adaptations, whatever one chooses to call them ... radically redefine the practice of translation, question the bipolar, hierarchical distinction between the author and the translator... subvert the concept of authorship" (Jarniewicz 2008: 104).

Just as the concept of authorship has been subverted more than once by many of the contributors to the publication in question, we as translators of these voices, accents, tongues - also translations of translations or "versions, imitations or adaptations" - would need to introduce our own explanatory voice in a number of situations in order not only to bring enjoyment, but also to enhance our reader's understanding and acceptance of the 'polyvocal' and the great diversity of expression so characteristic of contemporary Scottish writing.

Although due to the different voices present in the work there may be a certain loss in the process of translation, there will however also be gain if we do not shy away from elucidation in the form of an appropriate introduction, followed by commentaries and explanatory notes. Certain explanations and glossaries are given in the original, thus all the more reason to go one step further and explain/translate further for our inquisitive target reader. Works can be both 
enjoyable and educational, and in our translation of this great variety of Scottish voices, accents, tongues, that we are challenged with here for example, something that is not only of value to the Scot, but also to any reader appreciating the amazing richness and diversity present in foreign cultures may be made known outside the Scottish and English speaking world.

As a concluding remark, it is also necessary to remember what is so visible and of such great importance in the discussed anthology, that of the ever-present strain of warmth and humour that has its origins in so much of Robert Burns's own literary output, which has been so conducive to the past meeting the present. A present that, hopefully, Burns would be quite happy to be a part of.

University of Warsaw, Poland

\section{References}

Burns, R., 1956, Z wierszy szkockich [From Poems in Scots], intr. \& ed. S. Kryński, trans. Kierszys, Z., Kryński, S., \& L. Marjańska, Warszawa: PIW.

Crawford, R., ed., 2009, New Poems. Chiefly in the Scottish Dialect, Edinburgh: Polygon.

Gillies, W., 2000, 'Scottish Gaelic', in: France, P., ed., The Oxford Guide to Literature in English Translation, Oxford: Oxford University Press, 181183.

Jarniewicz, J., 2008, 'Scotland in Translation. Where the Foreign Helps to Define the Familiar' in: Grzegorzewska, M., \& Korzeniowska, A., eds., DUET Encounters, Warsaw: Institute of English Studies, University of Warsaw, 103-115.

Leonard, T., 1995, Intimate Voices. Selected Work 1965-1983, London: Vintage. Paz, O., 1992 ‘Translation: Literature and Letters’ in: Schulte, R., \& Biguenet, J. eds., Theories of Translation. An Anthology of Essays from Dryden to Derrida, Chicago and London: The University of Chicago Press, 152-162. 